\title{
Odpis podatkowy „1\%" jako źródło finansowania podmiotów ekonomii społecznej w Polsce - retrospekcja i projekcja poziomu zaangażowania społecznego
}

\section{Dorota Jegorow*}

\begin{abstract}
Streszczenie:
Jednym z podstawowych problemów podmiotów klasyfikowanych w ramach kategorii ekonomii społecznej jest utrzymanie niezależności i stabilności finansowej. Tymczasem uzależnienie od wsparcia publicznego zdominowało podstawowe źródła finansowania organizacji pożytku publicznego. W tym kontekście należy również rozpatrywać przychody generowane w ramach odpisu podatkowego "1\%". Ponad dziesięcioletnia obecność tego mechanizmu pozwoliła na zagospodarowanie 49\% ogólnej liczby podatników. Wyraźne wyhamowanie tendencji wzrostowej w tym zakresie świadczy o zbliżeniu się do potencjalnego maksimum absorpcyjnego. Sytuacja ta winna skłonić zarówno organizacje pozyskujące wysokie przychody w ramach odpisu podatkowego "1\%", jak i te planujące z tej formy wsparcia skorzystać, do przemyślenia nowej strategii marketingowej.
\end{abstract}

Słowa kluczowe: ekonomia społeczna, odpis podatkowy „1\%”, organizacja pożytku publicznego, sektor pozarządowy.

\section{Wprowadzenie}

Globalizacji przestrzeni gospodarczej regulowanej przez podmioty o zasięgu ponadnarodowym, $w$ tym instytucje finansowe i wielkie korporacje, wysokiej konsumpcji jednostek, a jednocześnie znaczącym rozmiarom ubóstwa towarzyszy wzrost nierówności społeczno-gospodarczych. Sytuacja ta dowodzi, że zawodzą rozwiązania przyjęte za właściwe i stosowane przez lata. W tym kontekście należy rozpatrywać zawężające podejście do ekonomii, ale jednocześnie respektujące jej olbrzymi dorobek. Na tym gruncie pojawiła się koncepcja ekonomii społecznej. W Polsce wzrost zainteresowania tym obszarem w wymiarze praktycznym należy wiązać z budową społeczeństwa obywa- telskiego, wyznaczoną transformacją ustrojową z 1989 r. Nie bez znaczenia pozostają strukturalne zmiany gospodarki bazujące na modelu neoliberalnym, a zwłaszcza masowa prywatyzacja zapoczątkowana $w$ ostatniej dekadzie XX w. I w końcu włączenie się Polski w politykę spójności, po akcesji do Unii Europejskiej, w ramach której ekonomia społeczna została wprost wskazana jako ważny wymiar polityki rozwoju. Formułowane wyzwania rozwojowe stworzyły potrzebę zagospodarowania nowej formy aktywno-

\section{* Dorota Jegorow}

Katedra Zastosowań Matematyki Instytut Ekonomii i Zarządzania Katolicki Uniwersytet Lubelski Jana Pawła II Al. Racławickie 14, 20-950 Lublin e-mail: dorotajegorow@kul.pl 
ści w przestrzeni społeczno-gospodarczej, w przypadku której przewidziano możliwość publicznego oraz prywatnego subsydiowania realizowanych działań. Do katalogu bezzwrotnych zewnętrznych transferów finansowych trafiających do podmiotów ekonomii społecznej w 2003 r. wprowadzono mechanizm finansowania oparty na "podatkowym odpisie jednoprocentowym". I tak, od 2004 r. polscy podatnicy przekazali na rzecz ogółu uprawnionych podmiotów łącznie prawie 4,3 mld zł, zwiększając jednocześnie swój udział w 2016 r. prawie sześćdziesięciokrotnie w porównaniu z rokiem bazowym.

Przeprowadzone badanie podejmuje rozważania w zakresie ilościowego wymiaru kształtowania się odpisów podatkowych "1\%" w układzie dynamicznym obejmującym lata 2004-2017'. Problem badawczy dotyczy określenia procesu absorbowania zbiorowości podatników analizowanym instrumentem w wymiarze ilościowym, w ujęciu dynamicznym, łącznie z uchwyceniem optimum zaangażowania. Przedmiot analizy wyznaczony został populacją organizacji uprawnionych do otrzymywania wsparcia w ramach "1\%". Zastosowane modelowanie retrospektywne zostało połączone z projekcją opartą na analizie regresji. Cel badania sprowadza się do identyfikacji trendów dotyczących odpisów podatkowych "1\%" w zakresie wielkości przychodów podmiotów uprawnionych do tej formy wsparcia, ich liczby oraz wielkości populacji podatników decydujących się na odpis. Wyznaczone prawidłowości oparte na modelowaniu matematycznym stanowią oryginalny wkład w badania empiryczne w zakresie ekonomii społecznej. Materiał badawczy stanowią dane pochodzące z opracowań Głównego Urzędu Statystycznego, Ministerstwa Finansów oraz Google Trends. Wyniki przeprowadzonej analizy, mającej charakter niestrukturalny, pozwalają twier-

Przyjęta cezura czasowa dotyczy maksymalnego zasięgu ogółu analizowanych zbiorów danych. dzić, że ponad dziesięcioletnia obecność „1\%" w krajowej praktyce społeczno-gospodarczej zbliża się do maksimum potencjalnego zasięgu w wymiarze liczby podatników skłonnych do dokonywania odpisów podatkowych oraz łącznej wysokości środków trafiających do uprawnionych organizacji. Zgodnie z zasadą ceteris paribus przyjęte wnioski opierają się na założeniu, że jedyną zmienną mającą wpływ na analizowane zjawisko jest czas. Postawiony cel badania oraz jego empiryczny charakter sprawiają, że rozważania teoretyczne osadzone zostały w ogólnej problematyce "1\%", ewolucji tego instrumentu oraz związku ekonomii społecznej z sektorem pozarządowym.

Wyniki przeprowadzonej analizy systematyzują i uzupełniają wiedzę w zakresie praktycznej implementacji ekonomii społecznej w Polsce. Sformułowane wnioski mogą ponadto zostać wykorzystane przez podmioty ekonomii społecznej w zakresie wyznaczania strategii rozwoju, a zwłaszcza planowania działań marketingowych związanych z pozyskiwaniem podatników skłonnych do dokonywania odpisu „1\%”, w szczególności w dłuższym okresie czasu. Tym samym spełnione zostało kryterium praktycznej użyteczności przeprowadzonych badań.

\section{Odpis podatkowy „1\%” w Polsce}

Podmiotami uprawnionymi do otrzymywania środków finansowych pochodzących z odpisu podatkowego "1\%" są jednostki posiadające status organizacji pożytku publicznego (OPP). Art. 20 ustawy z dnia 24 kwietnia 2003 r. o działalności pożytku publicznego i o wolontariacie określa zamknięty katalog podmiotów mogących ubiegać się o ten status. Są to: organizacje pozarządowe, organizacje utworzone przez kościoły i związki wyznaniowe oraz spółki akcyjne i spółki z ograniczoną odpowiedzialnością niedziałające w celu osiągnięcia zysku, których zakres działań ma charakter społecz- 
nie użyteczny. Brak jednoznacznego doprecyzowania co do zakresu możliwych do realizacji przedsięwzięć sprawia, iż w praktyce za pośrednictwem mechanizmu „1\%" można sfinansować prawie każde zadanie, z zastrzeżeniem, by nie nosiło ono znamion indywidualnego celu gospodarczego.

Fluktuacja gospodarek i funkcjonujących w niej podmiotów tworzą współcześnie systemy dynamiczne, w ramach których rozwiązania formalno-prawne stają się niejednokrotnie nadrzędne wobec indywidualnych skłonności i predyspozycji do gospodarowania. Odpis podatkowy "1\%" dedykowany organizacjom OPP w Polsce poddany został wieloaspektowym analizom uwzględniającym poziom przychodów beneficjentów pomocy, wraz z określeniem ich struktury w ujęciu czasowym [Piechota, 2015; Wygnański, 2016]. Zidentyfikowane zostały również motywy dokonywania przez uprawnionych podatników odpisów w ramach mechanizmu "1\%" [Adamiak, 2014]. W studia literaturowe wpisane zostały również kwestie ewolucji tego instrumentu w wymiarze formalno-prawnym oraz identyfikacja determinant stojących u podłoża dokonywania odpisu podatkowego "1\%" [Piechota, 2011; Piechota, 2015; Waniak-Michalak, Zarzycka, 2015]. W bogate studia literaturowe wpisane zostało również zagadnienie nadmiernego uzależnienia się sektora pozarządowego od bezzwrotnych środków egzogenicznych, w tym pochodzących z odpisu podatkowego „1\%”. I w końcu, w obszerny sposób opisane zostały zagadnienia związane z praktyką funkcjonowania OPP w sposób wykraczający poza założenia teoretyczne trzeciego sektora oraz ekonomii społecznej [Adamiak, 2014; Czetwertyński, 2016; Kietlińska, 2015; Jegorow, 2016; Jegorow, 2017a; Jegorow, 2017b; Piechota, 2015; Wygnański, 2016]. Problematyka oszacowania optimum społecznego zaangażowania w mechanizm "1\%" nie była dotychczas przedmiotem badań.
Pomimo wskazywania wielu wad "1\%", a nawet wobec faktu formułowania tez o „fałszywej filantropii" [Makowski, 2011; Perkowski, 2011], mechanizm ten funkcjonuje w Polsce w niezmienionej formie od wielu lat. Instrument ten wpisuje się w działania fundraisingowe funkcjonujące w praktyce gospodarczej od 2004 r. (na mocy rozwiązań prawnych wprowadzonych w 2003 r.) obok działalności odpłatnej, zbiórek publicznych, darowizn i sponsoringu. Pomimo niedługiej historii mechanizmu "1\%" był on już kilkakrotnie zmieniany, w tym m.in. w zakresie sposobu przekazywania środków finansowych do poszczególnych OPP, pomimo że wprowadzenie tego instrumentu zajęło siedem lat. Prace nad tym rozwiązaniem rozpoczęły się już bowiem w 1996 r. Idea „1\%" w Polsce była częścią szerszego projektu ustawodawczego mającego na celu poprawę warunków funkcjonowania sektora pozarządowego. Początkowo podatnik był zobowiązany samodzielnie przekazywać odpowiednią kwotę na rzecz wybranej OPP. Zaś od 2007 r. obowiązek rozliczeń został przeniesiony na urzędy skarbowe. Ustawodawca wprowadzając instrument „1\%" zapożyczył ideę m.in. ze sprawdzonych rozwiązań węgierskich (wprowadzonych już w 1997 r.) oraz słowackich (wprowadzonych w 2002 r.).

\section{Odpis podatkowy „1\%" jako źródło finansowania podmiotów ekonomii społecznej}

Biorąc pod uwagę fakt, iż w szerokim ujęciu organizacje klasyfikowane jako spełniające kryteria ekonomii społecznej podejmują się realizacji działań zorientowanych na osiągnięcie określonego celu mającego tło społeczno-ekonomiczne, należy część z nich, wpisujących się w ww. formy prawne, klasyfikować jako OPP. Jednocześnie nie można pomijać faktu, że na gruncie rozważań teoretycznych nie ma konsensusu co do tego, jak należy definiować podmioty ekonomii 
społecznej. Dotychczas nie wypracowano w Polsce jednej, obowiązującej w tym zakresie definicji oraz nie wprowadzono jednoznacznych kryteriów pozwalających określić, jakie jednostki można klasyfikować jako podmioty ekonomii społecznej [CRSG, 2013, s. 47]. W Krajowym Programie Rozwoju Ekonomii Społecznej (KPRES) z 2014 r. przyjęto definicję ekonomii społecznej w następującym brzmieniu: jest to „sfera aktywności obywatelskiej, która poprzez działalność ekonomiczną i działalność pożytku publicznego służy: integracji zawodowej i społecznej osób zagrożonych marginalizacją społeczną, tworzeniu miejsc pracy, świadczeniu usług społecznych użyteczności publicznej (na rzecz interesu ogólnego) oraz rozwojowi lokalnemu" [KPRES, 2014, s. 15]. Sklasyfikowanie OPP wśród podmiotów ekonomii społecznej, obok trzech innych kategorii wymienionych w KPRE, wiąże się z koniecznością wykazania aktywnej działalności mającej wymiar ekonomiczny, co nie oznacza jednak konieczności prowadzenia działalności gospodarczej. Niejednoznaczność ta, obok wielu innych, znalazła swoje odzwierciedlenie w "Rekomendacjach w zakresie weryfikacji statusu przedsiębiorstwa społecznego", w związku ze wsparciem ekonomii społecznej w ramach środków polityki spójności Unii Europejskiej (wynik uzgodnień pomiędzy Ministerstwem Rodziny, Pracy i Polityki Społecznej oraz Ministerstwem Rozwoju z dn. 26 kwietnia 2017 roku).

Wyraźną łączność terminów: OPP i ekonomia społeczna w wymiarze praktycznym potwierdza funkcjonowanie Departamentu Ekonomii Społecznej i Pożytku Publicznego w Ministerstwie Rodziny, Pracy i Polityki Społecznej. Biorąc pod uwagę fakt, że najpopularniejsze formy prawne podmiotów ekonomii społecznej tworzą fundacje, stowarzyszenia oraz spółdzielnie można przyjąć, że analizy oparte na populacji OPP są przybliżonym opisem gospodarki społecznej. Wynika to $\mathrm{z}$ faktu, że zrealizowane badanie $\mathrm{z}$ jednej strony wykroczyło poza populację podmiotów ekonomii społecznej, a z drugiej strony nie objęło swoim zasięgiem pełnego ich zbioru.

Zyskanie przez ekonomię społeczną w Polsce na znaczeniu w XXI w. w znacznej mierze determinowane jest adaptacją sprawdzonych w innych gospodarkach, relatywnie nowych form aktywności mającej kontekst społeczno-gospodarczy, a powstających w odpowiedzi na bezradność uznanych teorii opisujących z jednej strony niemal naturalną bezwarunkową sprawność rynków, a z drugiej strony efektywność interwencjonizmu państwowego. Dodatkowym wzmocnieniem zainteresowania tematyką ekonomii społecznej w Polsce była akcesja do Unii Europejskiej. Nowa organizacja państwa, w tym przyjęty model rozwoju, wkomponowane zostały w wytyczne wspólnotowe począwszy od stosowanej terminologii, poprzez inicjowanie atrakcyjnych pod względem potencjalnych źródeł finansowania projektów zorientowanych na wieloaspektowy wymiar ekonomii społecznej. Komisja Europejska uznała ekonomię społeczną „za jedno z działań, dzięki któremu promuje się integrację społeczną i zwalcza ubóstwo. (...) wsparcie dla przedsiębiorstw społecznych jest jednym z czynników zwiększających innowacje społeczne. Jest to niezmiernie istotne dla tworzenia polityki, która będzie w większym stopniu dostosowana do globalnych zmian społecznych" [MR, 2017].

Mechanizm wsparcia OPP oparty na odpisie podatkowym „1\%" funkcjonuje równolegle do wielu działań realizowanych na zalecenie administracji publicznej, zarówno rządowej, jak i samorządowej, oraz zadań finansowanych ze środków pochodzących z funduszy celowych. Katalog ten uzupełniają środki polityki spójności Unii Europejskiej, a zatem również środki publiczne, z których znacząca część ma charakter bezzwrotny. Udział poszczególnych źródeł finansowania w działalności podmiotów ekonomii społecz- 
nej nie jest jednak możliwy do precyzyjnego określenia z uwagi na brak jednoznacznie weryfikowalnych danych sprawozdawczych w tym zakresie. Rozwiązaniem tego problemu mają być rezultaty projektu "Zintegrowany System Monitorowania Sektora Ekonomii Społecznej", współfinansowanego ze środków Unii Europejskiej w ramach Programu Operacyjnego Wiedza Edukacja Rozwój 2014-2020. Projekt ten zakłada m.in. opracowanie metodologii gromadzenia, integracji i przetwarzania istniejących danych, a zabudżetowany został na poziomie $5 \mathrm{mln}$ zł. $\mathrm{Na}$ efekty należy jednak poczekać do końca czerwca 2020 roku [GUS, 2017b].

\section{Kontrowersje wokół odpisu podatkowego "1\%"}

Odpis podatkowy "1\%" stanowiący realną szansę na wzmocnienie ekonomii społecznej zazwyczaj prezentowany jest w wymiarze potencjalnych korzyści i sprawnej organizacji państwa $\mathrm{w}$ ramach społeczeństwa obywatelskiego. Ten życzeniowy wymiar charakteryzuje rozważania teoretyczne. Konfrontacja teorii z praktyką polskiej przestrzeni społeczno-gospodarczej nie pozwala jednak w wielu przypadkach na pozytywną weryfikację formułowanych na gruncie teoretycznym założeń. Zbyt rzadko podejmowane są dyskusje dotyczące kontrowersji i zagrożeń pojawiających się w tym zakresie. Akceptacja realizacji działań sprzecznych z ideą pożytku publicznego obejmuje m.in. kwestię subkont, dających w praktyce możliwość wspierania osób fizycznych, finansowanie celów nie mających związku z pożytkiem publicznym, korporacyjność, czy opieranie niemal całej działalności na środkach pochodzących z odpisów podatkowych w ramach „1\%" [Adamiak, 2014, s. 83; Piechota, 2015, s. 11-12; Kietlińska, 2015, s. 110-111]. Nie bez znaczenia pozostaje wykorzystywanie sektora pozarządowego do działań mających podłoże polityczne. Wprowadzenie odpisu podatkowego
"1\%" doprowadziło m.in. do wytworzenia się mechanizmu rynkowego z naturalnymi dla niego działaniami bazującymi na kalkulacjach ekonomicznych [Czetwertyński, 2016, s. 82]. To z kolei prowadzi do marginalizacji celów społecznie użytecznych kosztem realizacji partykularnych interesów, zarówno indywidualnych, jak i zbiorowych. Formułowane w tym zakresie krytyczne wnioski rekomendują potrzebę wprowadzenia zmian w mechanizmie "1\%". To z kolei wymaga nowych rozwiązań legislacyjnych, które jednak nie znalazły się dotychczas w kręgu zainteresowania ustawodawcy. Zalecana przed laty konieczność prowadzenia społecznej kontroli "1\%" jest nadal jedynym skutecznym mechanizmem pozwalającym na identyfikację nieprawidłowości pojawiających się w tym obszarze. Jest to istotne m.in. z uwagi na fakt, że praktyka funkcjonowania podmiotów ekonomii społecznej okazuje być się trudniejsza w porównaniu do działalności pozostałych podmiotów gospodarki narodowej. Specyfika wielu przedsięwzięć wpisanych w działalność podmiotów ekonomii społecznej wykracza poza zainteresowanie sektora biznesu lub jest wynikiem nieefektywności działań realizowanych w ramach sektora publicznego. Zatem wszelkie nadużycia podejmowane w osnowie "1\%" winny być bezwzględnie piętnowane dla dobra pozostałych społecznie użytecznych organizacji.

To, że wymiar finansowania podmiotów ekonomii społecznej nie jest doskonały, znajduje odzwierciedlenie w wielu pracach koncepcyjnych wykraczających poza granice Polski [Herbst, 2012, s. 9-10; Yunus, 2011, s. 183-188, Yunus, 2013, s. 189-191]. Wynika to m.in. z faktu, że ekonomia społeczna wymaga specyficznego kapitału finansowego, określanego przez niektórych jako „cierpliwy kapitał", który charakteryzuje się długim okresem zaangażowania środków i karencji w spłacie oraz niskim kosztem i poziomem przekazania kontroli zarządzania instytucją [Królikowska, 2005, s. 79; Grzybowska, Ruszewski, 2010, 
s. 91]. W tym kontekście „1\%" należy postrzegać jako inwestycję państwową osadzoną w realiach funkcjonujących na pograniczu trzech sektorów.

\section{Beneficjenci „1\%" - retrospekcja i projekcja}

Organizacje korzystające z odpisu podatkowego "1\%" tworzą populację bardzo zróżnicowaną wewnętrznie. Jednostki pozyskując wysokie kwoty w ramach odpisu podatkowego są zazwyczaj podmiotami działającymi profesjonalnie (zatrudniają wyspecjalizowanych pracowników i wykorzystują fachową komunikację z otoczeniem) lub są podmiotami gromadzącymi osoby podzielające określone i zbliżone problemy, głównie związane z obszarem zdrowia i opieki społecznej. Większość OPP charakteryzuje jednak prosta struktura organizacyjna i brak zarejestrowanej działalności gospodarczej. Fakt ten przesądza o tym, że dynamiczny rozwój ekonomii społecznej nie determinuje równie szybkiego procesu tworzenia przedsiębiorstw społecznych. OPP są zazwyczaj jednostkami opierającymi swoją działalność na niewielkich zasobach ludzkich, infrastrukturalnych i finansowych oraz są to podmioty sprowadzające swoją aktywność do wymiaru lokalnego. „Budżetowe rozwarstwienie” OPP [Adamiak i in., 2016, s. 14] nie zmienia faktu, że wspólnym problemem ogółu organizacji jest „uzależnienie" od finansowania środkami publicznymi [Solecki, 2013, s. 184], w tym odpisem podatkowym „1\%" [Piechota, 2015, s. 186-187].

Na przestrzeni lat 2004-2015 liczba zarejestrowanych OPP wzrosła z 2,2 tys. do 9,0 tys. W 2015 r. aktywną działalność prowadziło 8,8 tys. OPP, co stanowiło 10\% ogółu podmiotów sektora non-profit mogących ubiegać się ten status [GUS, 2017a]. Fakt, iż ostatnia dekada charakteryzowała się systematycznym przyrostem ilościowym sektora pozarządowego, w tym organizacji posiadających status OPP, nie oznacza, że proces ten będzie kontynuowany przez kolejne lata w tym samym natężeniu. Modelowanie analityczne bazując na funkcji trendu i oparte na szeregu czasowym² liczby OPP z lat 2004-2015 zwraca bardzo wysoką wartość współczynnika determinacji $\left(R^{2}=0,9896\right)^{3}$ i niską wartość błędu standardowego oceny modelu $(S=0,247)^{4}$ w przypadku funkcji kwadratowej (funkcja liniowa: $\left.R^{2}=0,8693, S=0,831\right)^{5}$. Rozpatrując ten model rozwoju nie należy oczekiwać statystycznie istotnego przyrostu ilościowego OPP w populacji ogółu podmiotów gospodarki narodowej w kolejnych latach, bowiem nasycenie rynku nastąpiło na przełomie lat 2013 i 2014, przy poziomie 8,86 tys. ${ }^{6}$ Otrzymany wynik pokrywa się z liczbą organizacji prowadzących aktywną działalność w 2015 r.

Przeprowadzone modelowanie matematyczne daje formalne podstawy do twierdzenia o zmniejszaniu się liczby OPP w kolejnych latach. Jednak każda predykacja, aby wnosiła realną wartość poznawczą, powinna uwzględniać korektę wynikającą

\footnotetext{
Zmienną zależną jest w tym przypadku analizowana cecha, zmienną niezależną jest czas ( $\mathrm{x}$ ), a jednostką jest rok. Modelowanie oparte na szeregach czasowych i wykorzystujące dopasowanie funkcją trendu pozwala nie tylko na precyzyjne wykrywanie natury analizowanych zjawisk, ale również formułowanie prognoz charakteryzujących się wysoką oceną exante.

Wartość współczynnika mieści się w przedziale od 0 do 1. Wyższa jego wartość świadczy o relatywnie lepszym dopasowaniu teoretycznej funkcji trendu do danych empirycznych.

Niższa wartość błędu świadczy o relatywnie lepszym dopasowaniu teoretycznej funkcji trendu do danych empirycznych.

Formalnie model liniowy należy również uznać za dostatecznie dobrze dopasowany do danych empirycznych. Relatywnie jednak jest on gorszy od funkcji kwadratowej. Koncypowanie oparte na funkcji trendu wyrażonej modelem liniowym nie znajduje zatem uzasadnienia. Ograniczenie rozważań do dwóch funkcji nie zapewnia optymalizacji wyboru. Biorąc jednak pod uwagę wartości zastosowanych miar dopasowania należy stwierdzić, że nie ma podstaw do uznania przeprowadzonego modelowania jako statystycznie nieistotnego.

Obliczenia własne w oparciu o własności funkcji kwadratowej związane ze zmianą monotoniczności, wyznaczoną wierzchołkiem paraboli: $q=-\frac{\Delta}{4 a}$ dla $p=-\frac{b}{2 a}$.
} 
z nadmiernego upraszczania rzeczywistości za pomocą reguł matematycznych. Nie chodzi zatem o zmniejszanie się liczby OPP, ale o istotną zmianę dynamiki przyrostu tego typu organizacji w ogólnej ich populacji przy założeniu zasady ceteris paribus. Czyli przy zachowaniu zbliżonych warunków rynkowych oraz niezmienionych rozwiązaniach formalno-prawnych wprawdzie liczba OPP nadal będzie się zwiększała, to jednak w tempie znacznie mniejszym, niż miało to miejsce na przestrzeni lat 2004-2015, gdy średnioroczny przyrost kształtował się na poziomie $12,5 \%$. Skracając szereg czasowy do okresu 2010-2015 wartość analizowanego wskaźnika zmniejsza się do poziomu niespełna 1,9\%.

\section{Wykres 1. Liczba OPP w latach 2004-2015 (w tys.)}

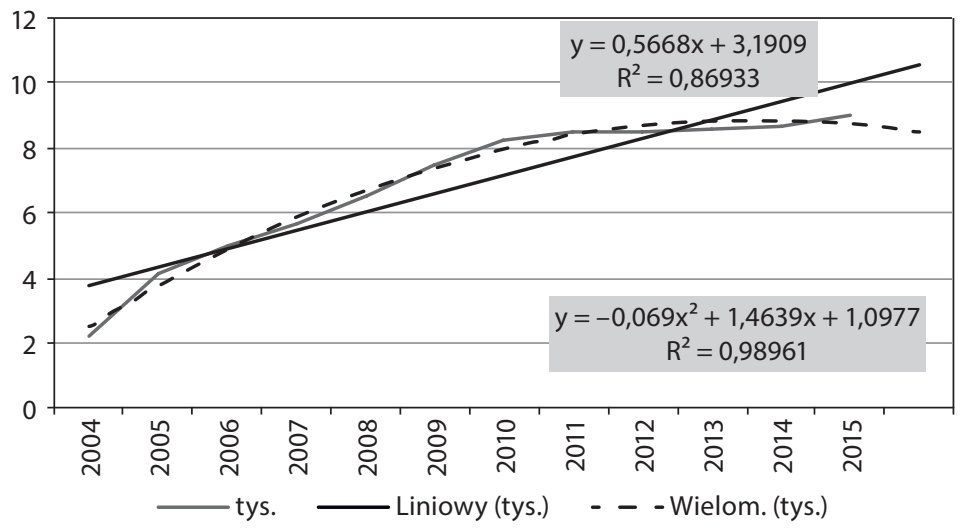

Źródło: opracowanie własne na podstawie danych: [GUS, 2017a].

Odpis podatkowy "1\%" jako nowy instrument finansowania OPP został wdrożony w praktykę gospodarczą w 2004 r., obejmując wówczas zaledwie 0,33\% ogólnej liczby podatników [Piechota, 2015, s. 43]. Kwota, jaką pozyskały wówczas OPP, nie przekroczyła 10,4 $\mathrm{mln}$ zł. Liczba podatników decydujących się na przekazanie "1\%" odpisu podatkowego na rzecz OPP w latach 2004-2016 rosła średniorocznie o 53,0\%. Wyraźnie gasnące tempo zmian dokonujące się $\mathrm{w}$ tym zakresie określa miara analizowanego wskaźnika wyznaczona dla lat 2010-2016 i równa 7,3\%. W 2016 r. do OPP trafiły środki pochodzące od populacji podatników dokonujących odpisu "1\%" w 2015 r. pokrywającej 49\% swojej zbiorowości (tj. jednocześnie 59\% liczby podatników wykazujących w zeznaniach należny podatek) [MF, 2016, s. 2]. W 2010 r. wskaźnik ten ktałtował się na poziomie 33\% [MF, 2010, s. 2]. Podobnie jak w przypadku liczby OPP i tym razem ana- lityczne dopasowanie funkcji trendu do szeregu czasowego analizowanej cechy zwraca funkcję kwadratową jako charakteryzującą się najwyższą dobrocią dopasowania do danych empirycznych $\left(R^{2}=0,9636, S=1\right.$ 039,857; funkcja liniowa: $R^{2}=0,9418, S=1$ 253,650). W tym przypadku istotne wyhamowanie wzrostu liczby podatników przekazujących „1\%" podatku na OPP powinno nastąpić około 2021 r. przy poziomie $15 \mathrm{mln}^{7}$.

Analogicznie do obu zbadanych wcześniej cech również przychody OPP z tytułu odpisów podatkowych w ramach "1\%" systematycznie rosły w latach 2004-2016, wyhamowując w drugiej dekadzie XXI w. Średnioroczny przyrost przychodów OPP z "1\%" wlatach 2004-2016 ukształtował się na poziomie $40,5 \%$, natomiast w latach 2010 2016 nie przekroczył 9,4\%. W porównaniu do

Przyjmując za funkcję trendu wielomian stopnia drugiego 
wcześniej analizowanych cech w tym przypadku tempo wzrostu w drugiej dekadzie XXI w. okazało być się zdecydowanie wyższe. Potwierdza to fakt, iż znaczące wyhamowanie przychodów OPP z tytułu odpisu podat- kowego "1\%" powinno nastąpić w 2023 r. z wynikiem $685 \mathrm{mln}$ zł, przyjmując jako optymalny model trendu wyrażony funkcją kwadratową ( $R^{2}=0,9609, S=45,361$; funkcja liniowa: $R^{2}=0,9441, S=51,687$ ).

\section{Wykres 2. Liczba podatników przekazujących „1\%” na OPP w latach 2004-2016 (w tys.)}

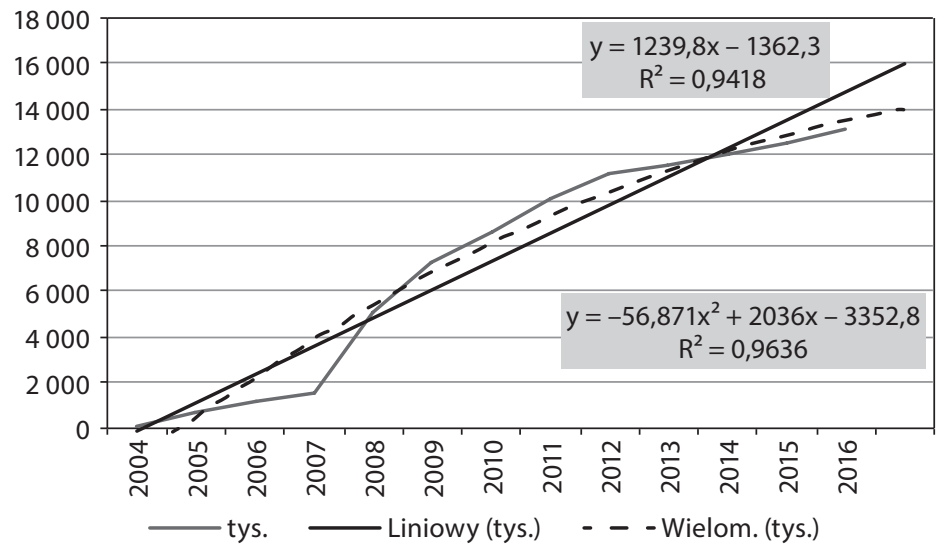

Źródło: opracowanie własne na podstawie danych: [MF, 2016, s. 6].

\section{Wykres 3. Przychody OPP z „1\%" w latach 2004-2016 (w mln zł)}

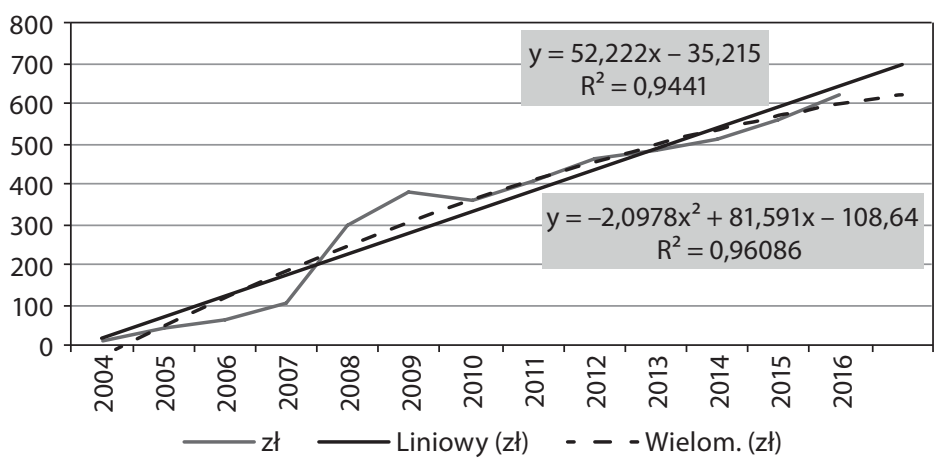

Źródło: opracowanie własne na podstawie danych: [MF, 2016, s. 6].

Udział odpisów podatkowych "1\%" w należnym podatku PIT (podatek dochodowy od osób fizycznych) również regularnie zwiększał się na przestrzeni lat 2010-2016 w sposób zbliżony do zmian wyznaczonych w przypadku analizowanych wcześniej cech,

8 Analiza oparta została na skróconym szeregu czasowym, co wynika z ograniczonego dostępu do danych. tj. dynamika zmian wpisana w optymalny model kwadratowy charakteryzowała się wyhamowującym tempem wzrostu (funkcja kwadratowa: $R^{2}=0,9551, S=0,011$; funkcja liniowa: $\left.R^{2}=0,9210, S=0,013\right)$. W badanym zakresie jednak szersze analizy nie mają zastosowania z uwagi na niewielką liczbę dostępnych informacji składających się na analizowany szereg czasowy. 


\section{Wykres 4. Udział procentowy odpisu „1\%” w należnym podatku PIT}

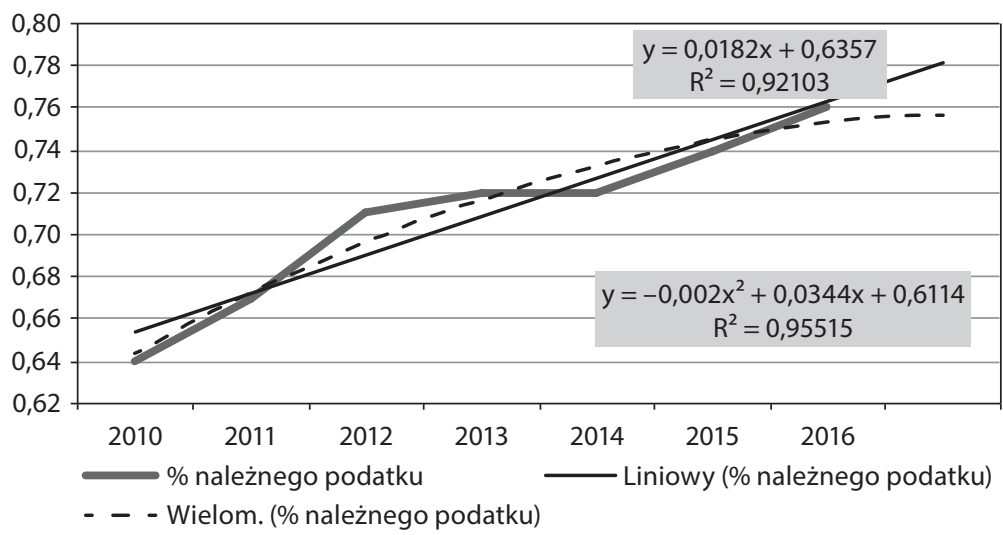

Źródło: opracowanie własne na podstawie danych: [MF, 2017] - w zakresie kwot 1\% należnego podatku dochodowego od osób fizycznych przekazanych organizacjom pożytku publicznego w latach 2009-2015 (wykazywanych w latach 2010-2016).

Populacja beneficjentów odpisu podatkowego "1\%" jest bardzo zróżnicowana, w dużej mierze w zakresie przychodów generowanych w ramach środków przekazywanych na subkonta [Wygnański, 2016, s. 96]. Sytuacja ta znacząco ogranicza rozpoznanie założonego przedmiotu badań przy wykorzystaniu metod statystyki opisowej. Bardzo wysoka wartość współczynnika zmienności losowej nie pozwala na formułowanie wiążących wniosków w oparciu o miary położenia. Sytuacja ta ma związek z wyraźną asyme- trią prawostronną populacji beneficjentów odpisu podatkowego „1\%”, w przypadku której dominują podmioty otrzymujące niewielkie kwoty (na co wskazuje wysoka dodatnia wartość współczynnika skośności). Pomimo że lider absorpcji odpisu podatkowego „1\%" w 2016 r. otrzymał ponad $144 \mathrm{mln}$ zł, to jednocześnie 50\% OPP otrzymało niewiele ponad 5 tys. zł (mediana), 25\% OPP otrzymało wsparcie na poziomie nie przekraczającym 1,7 tys. zł (kwartyl 1), a 75\% OPP pozyskało w ramach „1\%" środki sięgające 16 tys. zł.

Tabela 1. Wybrane statystyki położenia i rozproszenia dla beneficjentów „1\%" w latach 2011-2016 (na podstawie odpisów 2010-2015)

\begin{tabular}{|c|c|c|c|c|c|c|c|c|}
\hline Rok & Średnia & Kwartyl1 & Mediana & Kwartyl2 & $\begin{array}{c}\text { 0dchylenie } \\
\text { standardowe }\end{array}$ & $\begin{array}{c}\text { Współczynnik } \\
\text { zmienności }\end{array}$ & $\begin{array}{c}\text { Współczynnik } \\
\text { skośności }\end{array}$ & Max \\
\hline 2016 & 76162,01 & 1681,05 & 5037,80 & 16038,18 & 1673893,11 & $2198 \%$ & 79,35 & 144082857,97 \\
\hline 2015 & 70685,02 & 1712,78 & 5027,80 & 16139,30 & 1589227,22 & $2248 \%$ & 80,20 & 136189516,87 \\
\hline 2014 & 68240,78 & 1767,49 & 5275,80 & 16421,21 & 1519463,84 & $2227 \%$ & 78,99 & 127036846,65 \\
\hline 2013 & 67516,48 & 1907,03 & 5450,10 & 17764,68 & 1429835,64 & $2118 \%$ & 77,62 & 117182981,43 \\
\hline 2012 & 66673,83 & 1940,80 & 5735,20 & 18529,35 & 1350630,58 & $2026 \%$ & 76,18 & 108708265,91 \\
\hline 2011 & 61264,56 & 1924,50 & 5788,80 & 18541,44 & 1135708,15 & $1854 \%$ & 73,37 & 88805662,39 \\
\hline
\end{tabular}

Źródło: opracowanie własne na podstawie danych: [MF, 2017].

Pozytywne trendy w zakresie poszerzenia obecności w przestrzeni społeczno- -gospodarczej OPP, wzrost liczby podatników decydujących się na wsparcie wybranych 
organizacji w ramach odpisu podatkowego „1\%" i, w końcu, wzrost realnych przychodów uprawnionych podmiotów wyraźnie wyhamowują. Sytuacja ta winna skłaniać do refleksji organizacje korzystające z „1\%” i planujące korzystać w przyszłości z tej formy wsparcia w zakresie budowy właściwych relacji z podatnikami gotowymi do dokonywania odpisu podatkowego. Organizacje partycypujące w przychodach z mechanizmu "1\%" powinny zorientować swoje działania na wzmocnienie relacji z podatnikami, którzy dokonywali już wcześniej odpisów podatkowych w tym zakresie. Z kolei nowe podmioty starające się o status OPP mają zdecydowanie bardziej utrudnione zadanie w porównaniu do sytuacji sprzed dekady. W grę wchodzi bowiem docieranie do podatników mających już doświadczenie $\mathrm{w}$ dokonywaniu odpisu podatkowego „1\%" na rzecz innych organizacji. Niezależnie od potencjału i doświadczenia OPP należy wziąć pod rozwagę fakt, że narzędzia marketingowe dają mniejszą efektywność w pozyskiwaniu przychodów w ramach "1\%" niż działania z zakresu public relations [Piechota, 2015, s. 187].

\section{Zainteresowanie OPP i „1\%” wśród internautów}

Poszukując wzorca przebiegu procesów, w których naczelne miejsce zajmują ludzie, współcześnie można z powodzeniem korzystać z zaawansowanych technologii informacyjno-komunikacyjnych. Niezwykle użytecznym narzędziem w tym zakresie jest Google Trends ${ }^{9}$, które od lat wykorzystywane jest

Dane Google Trends stanowią alternatywę dla innych źródeł, które są niedostępne w istniejących zbiorach danych, bądź pojawiają się z opóźnieniem lub których kolekcja jest czasochłonna i kosztowna. Zaletą wykorzystania zapytań z wyszukiwarek internetowych jest szybkość i dostępność [Bulczak, 2014, s. 87]. Istotność i precyzję informacji pochodzących z wyszukiwarek internetowych w identyfikowaniu procesów społecznych i gospodarczych oraz prognozowaniu ma pokrycie w systematycznie zwiększającym się dorobku naukowym [Cooper i in., 2005; Ettredge i in., 2005; Goel i in., 2010; Choi, Varian, 2012; Vosen, Schmidt, 2011]. w marketingu. Statystyki powstające na bazie haseł wyszukiwanych przez internautów pozwalają na identyfikację trendów i wahań sezonowych wybranych zjawisk. Korzystając z tego rozwiązania analitycznego okazuje się, że w przypadku trzech badanych kategorii haseł („1\%", "1 \%" oraz "1 procent") najwyższa częstotliwość wyszukiwań w okresie od kwietnia 2004 r. do maja 2017 r. przypadła na kwiecień 2007 r., natomiast w przypadku dwóch pozostałych haseł („opp" i „organizacja pożytku publicznego") najwyższy odsetek wskazań odnotowany został w kwietniu 2008 r. $^{10}$. Tym samym należy stwierdzić, że to przełom lat 2007/2008 wyznacza punkt zwrotny w zainteresowaniu analizowaną problematyką. Otrzymane wyniki nie przesądzają jednak zarówno o fakcie zdobycia pożądanej wiedzy, świadomości społecznej, jak również o wyhamowaniu zainteresowania przedmiotową problematyką. Kwestia ta wymaga odrębnego rozpoznania naukowego uwzględniającego profil internautów poszukujących określonych informacji, ze szczególnym uwzględnieniem reprezentowanej strony, tj. dokonującej odpisu podatkowego lub korzystającej ze wsparcia.

Niezależnie od postawionych pytań faktem jest, iż w okresie od 2004 r. do 2011 r. wyraźnie zwiększało się zainteresowanie wiedzą obejmującą wyodrębnione w analizie hasła. Związek z terminem dokonywania rozliczeń podatkowych wydaje się w tym przypadku bezsprzeczny.

\footnotetext{
${ }^{10}$ Dobór haseł warunkujących rzetelność analizy związany jest doświadczeniem i intuicją badacza. Aplikacja Google Trends wspomaga decyzje w tym zakresie poprzez rozszerzanie katalogu fraz w oparciu o pierwsze wprowadzone hasło. Aplikacja analizując ciąg znaków pod uwagę bierze każdy wprowadzony symbol. Zatem nie bez znaczenia pozostaje wprowadzenie np. spacji. Przypadkowość jest domeną aplikacji Google Trends, tak jak ogółu badań statystycznych. Eliminacja błędów w tym zakresie pozostaje również w gestii badacza. Zgodnie z konstrukcją aplikacji najwyższy odsetek wynosi 100 i tworzy układ odniesienia dla pozostałych porównywanych kategorii mieszczących się w analizowanym przedziale czasowym.
} 
Wykres 5. Częstość wyszukiwania haseł związanych z „1\%” w latach 2004-2017 - analiza indywidualna

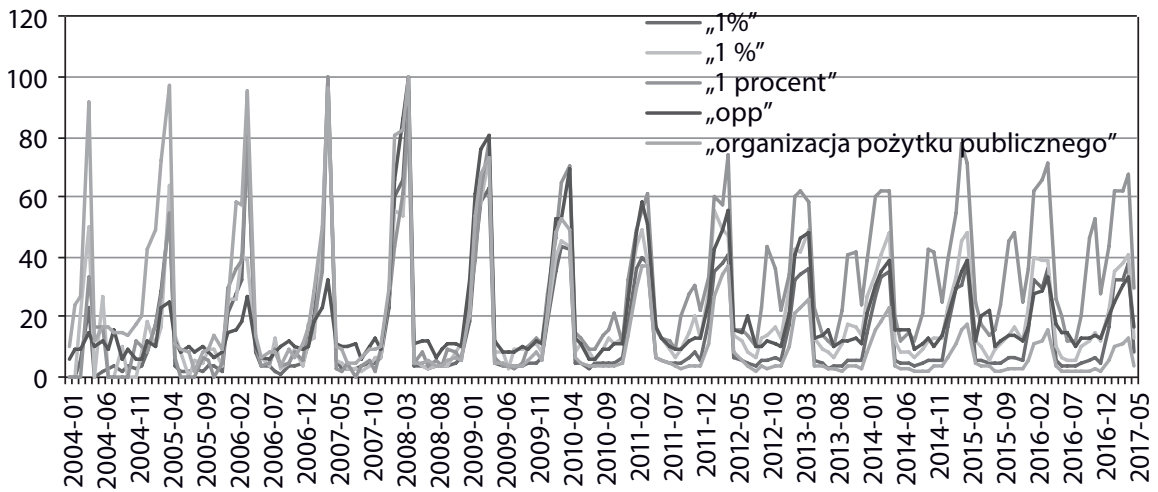

Źródło: opracowanie własne na podstawie danych Google Trends (stan na 31.05.2017).

\section{Wykres 6. Częstość wyszukiwania haseł związanych z „1\%” w zawężeniu do wyników rejestrowanych w kwietniu w latach 2004-2017 - analiza indywidualna}

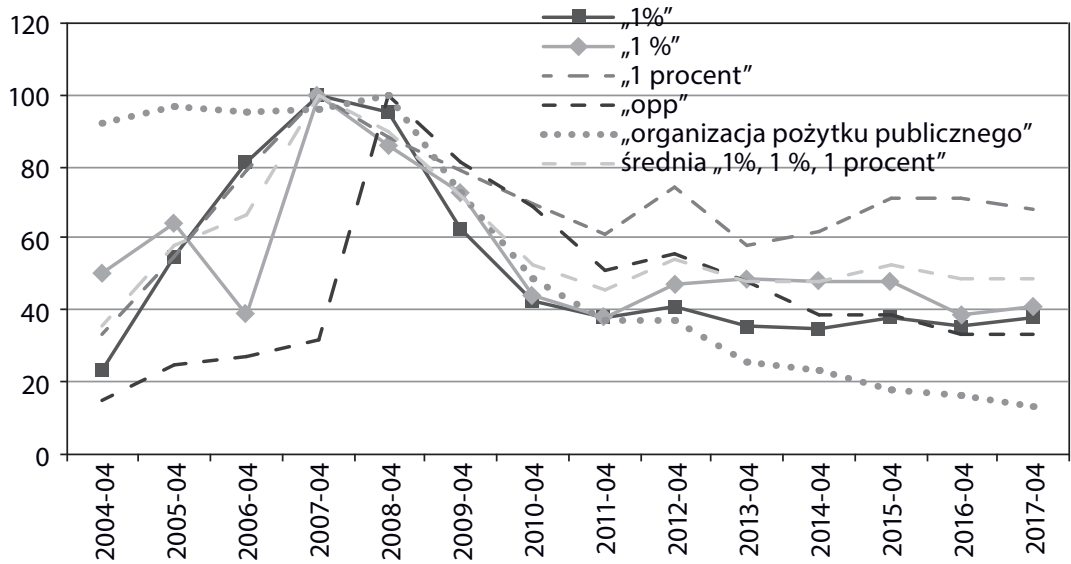

Źródło: opracowanie własne na podstawie danych Google Trends (stan na 31.05.2017).

Spośród uwzględnionych w analizie haseł internauci najczęściej wpisywali "1\%", a w następnej kolejności „opp”, na które przypadło łącznie $73 \%$ zapytań. Wybrane hasła nie wyczerpują szerokiej palety zapytań dotyczących odpisu podatkowego w ramach "1\%", stanowią jednak zbiór relatywnie najczęściej wyszukiwanych fraz. Ograniczając rozważania do obu haseł mających dominujący wpływ na analizowaną problematykę należy stwierdzić, że wyraźny spadek wskaźnika zapytań po 2008 r., zdecydowanie wygasł po 2011 r. Stała wartość analizowanych wskaźników potwierdza wcześniej formułowane wnioski o gasnącym potencjale "1\%" w zakresie nie tyle eksploatacyjnym, co ekspansyjnym, obejmującym zwiększanie liczby podatników skłonnych do dokonywania stosowanego odpisu podatkowego oraz przychodów OPP pochodzących z tego tytułu. 
Wykres 7. Struktura natężenia wyszukiwania haseł związanych z „1\%" w latach 2004-2017 analiza porównawcza

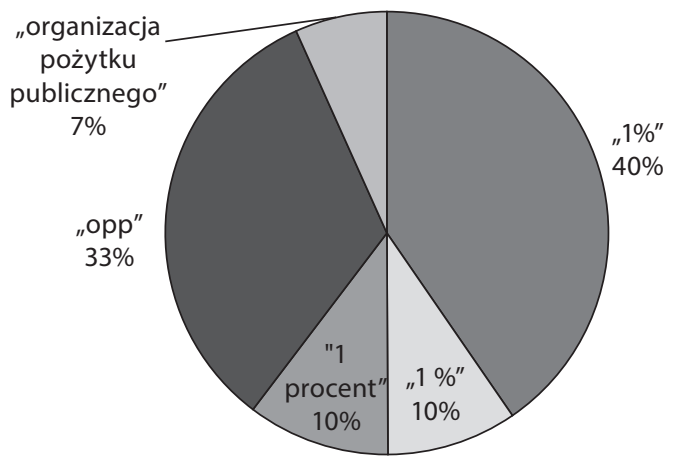

Źródło: opracowanie własne na podstawie danych Google Trends (stan na 31.05.2017).

Tabela 2. Analiza korelacji natężenia haseł związanych z „1\%" w latach 2004-2017

\begin{tabular}{|c|c|c|c|c|}
\hline Test korelacji: „1\%” & „1\%" & "1 procent" & „opp" & $\begin{array}{c}\text { "organizacja pożytku } \\
\text { publicznego" }\end{array}$ \\
\hline Pearsona & $\begin{array}{l}, 935^{* *} \\
, 000\end{array}$ & $\begin{array}{l}, 836^{* *} \\
, 000\end{array}$ & $\begin{array}{l}, 844^{* *} \\
, 000\end{array}$ & $\begin{array}{l}, 844^{* *} \\
, 000\end{array}$ \\
\hline Tau b Kendalla & $\begin{array}{l}, 774^{* *} \\
, 000\end{array}$ & $\begin{array}{l}, 693^{* *} \\
, 000\end{array}$ & $\begin{array}{l}, 668^{* *} \\
, 000\end{array}$ & $\begin{array}{l}, 399 * * \\
, 000\end{array}$ \\
\hline rho Spearmana & $\begin{array}{l}, 892^{* *} \\
, 000\end{array}$ & $\begin{array}{l}, 853^{* *} \\
, 000\end{array}$ & $\begin{array}{l}, 813^{* *} \\
, 000\end{array}$ & $\begin{array}{l}, 537^{* *} \\
, 000\end{array}$ \\
\hline Test korelacji: „1\%” & „1\%" & „1 procent" & „opp" & $\begin{array}{l}\text { "organizacja pożytku } \\
\text { publicznego" }\end{array}$ \\
\hline Pearsona & $\begin{array}{l}, 935^{* *} \\
, 000\end{array}$ & $\begin{array}{l}, 876^{* *} \\
, 000\end{array}$ & $\begin{array}{l}, 836^{* *} \\
, 000\end{array}$ & $\begin{array}{l}, 759^{* *} \\
, 000\end{array}$ \\
\hline Tau b Kendalla & $\begin{array}{l}, 774^{* *} \\
, 000\end{array}$ & $\begin{array}{l}, 704^{* *} \\
, 000\end{array}$ & $\begin{array}{l}, 622^{* *} \\
, 000\end{array}$ & $\begin{array}{l}, 354^{* *} \\
, 000\end{array}$ \\
\hline rho Spearmana & $\begin{array}{l}, 892^{* *} \\
, 000\end{array}$ & $\begin{array}{l}, 869^{* *} \\
, 000\end{array}$ & $\begin{array}{l}, 782^{* *} \\
, 000\end{array}$ & $\begin{array}{l}, 504^{* *} \\
, 000\end{array}$ \\
\hline Test korelacji: „1 procent” & ,1\%" & „1\%” & „opp" & $\begin{array}{l}\text { "organizacja pożytku } \\
\text { publicznego" }\end{array}$ \\
\hline Pearsona & $\begin{array}{l}, 836^{* *} \\
, 000\end{array}$ & $\begin{array}{l}, 876^{* *} \\
, 000\end{array}$ & $\begin{array}{l}, 757^{* *} \\
, 000\end{array}$ & $\begin{array}{l}, 541^{* *} \\
, 000\end{array}$ \\
\hline Tau b Kendalla & $\begin{array}{l}, 693 * * \\
, 000\end{array}$ & $\begin{array}{l}, 704^{* *} \\
, 000\end{array}$ & $\begin{array}{l}, 628^{* *} \\
, 000\end{array}$ & $\begin{array}{l}, 172^{* *} \\
, 002\end{array}$ \\
\hline rho Spearmana & $\begin{array}{l}, 853^{* *} \\
, 000\end{array}$ & $\begin{array}{l}, 869^{* *} \\
, 000\end{array}$ & $\begin{array}{l}, 815^{* *} \\
, 000\end{array}$ & $\begin{array}{l}, 300^{* *} \\
, 000\end{array}$ \\
\hline Test korelacji: „opp” & 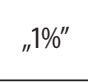 & "1\%" & "1 procent" & $\begin{array}{l}\text { "organizacja pożytku } \\
\text { publicznego" }\end{array}$ \\
\hline $\begin{array}{cc}\text { Pearsona } & \text { WK } \\
& p\end{array}$ & $\begin{array}{l}, 844^{* *} \\
, 000\end{array}$ & $\begin{array}{l}, 836^{* *} \\
, 000\end{array}$ & $\begin{array}{l}, 757^{* *} \\
, 000\end{array}$ & $\begin{array}{l}, 668^{* *} \\
, 000\end{array}$ \\
\hline
\end{tabular}




\section{cd. tabeli 2}

\begin{tabular}{|c|c|c|c|c|}
\hline Tau b Kendalla & $\begin{array}{l}, 668^{* *} \\
, 000\end{array}$ & $\begin{array}{l}, 622^{* *} \\
, 000\end{array}$ & $\begin{array}{l}, 628^{* *} \\
, 000\end{array}$ & $\begin{array}{l}, 309^{* *} \\
, 000\end{array}$ \\
\hline rho Spearmana & $\begin{array}{l}, 813^{* *} \\
, 000\end{array}$ & $\begin{array}{l}, 782^{* *} \\
, 000\end{array}$ & $\begin{array}{l}, 815^{* *} \\
, 000\end{array}$ & $\begin{array}{l}, 437^{* *} \\
, 000\end{array}$ \\
\hline $\begin{array}{l}\text { Test korelacji: „organizacja } \\
\text { pożytku publicznego" }\end{array}$ & , & „1\%” & "1 procent" & „opp" \\
\hline Pearsona & $\begin{array}{l}, 844^{* *} \\
, 000\end{array}$ & $\begin{array}{l}, 759^{* *} \\
, 000\end{array}$ & $\begin{array}{l}, 541^{* *} \\
, 000\end{array}$ & $\begin{array}{l}, 668^{* *} \\
, 000\end{array}$ \\
\hline Tau b Kendalla & $\begin{array}{l}, 399 * * \\
, 000\end{array}$ & $\begin{array}{l}, 354^{* *} \\
, 000\end{array}$ & $\begin{array}{l}, 172^{* *} \\
, 002\end{array}$ & $\begin{array}{l}, 309^{* *} \\
, 000\end{array}$ \\
\hline rho Spearmana & $\begin{array}{l}, 537^{* *} \\
, 000\end{array}$ & $\begin{array}{l}, 504^{* *} \\
, 000\end{array}$ & $\begin{array}{l}, 300^{* *} \\
, 000\end{array}$ & $\begin{array}{l}, 437^{* *} \\
, 000\end{array}$ \\
\hline
\end{tabular}

WK - współczynnik korelacji

p - Istotność (dwustronna)

**korelacja jest istotna na poziomie 0,01 (dwustronnie)

Źródło: opracowanie własne.

Właściwość doboru wybranych do badania haseł potwierdzają wyniki analizy korelacji oparte na trzech niezależnych testach. Wynika z nich, że wskaźniki wyszukiwania poszczególnych haseł układają się w szeregi charakteryzujące się statystycznie istotną zależnością. Przy czym najsłabsza siła zależności łączy ogół przyjętych kategorii z hasłem „organizacja pożytku publicznego"11.

Niezależnie od zarysowanych trendów zainteresowanie tematyką OPP oraz odpisem procentowym w ramach "1\%" wśród internautów jest faktem. Niewielka liczba zapytań dotycząca przedmiotowych haseł nie pozwoliłaby na wygenerowanie zaprezentowanych statystyk z aplikacji Google Trends.

\section{Podsumowanie}

Przeprowadzona analiza ex post połączona z projekcją opartą na modelach trendu dowodzi, iż stopniowo wyhamowują tendencje wzrostowe w zakresie liczby podatników dokonujących odpisu "1\%" oraz wartości przychodów OPP z tego tytułu. Wyczerpu-

1 Najsilniejszy związek występuje w przypadku WK bliskiego 1, a najsłabszy, gdy WK zbliża się do 0. jący się potencjał odpisu podatkowego dokonywanego w ramach "1\%" nie oznacza braku możliwości efektywnego wykorzystania tego instrumentu pomocowego $\mathrm{w}$ funkcjonowaniu nowych podmiotów ekonomii społecznej. Należy jednak liczyć się z tym, że pozyskanie podatników skłonnych do przekazania "1\%" na rzecz danej OPP będzie wiązało się z koniecznością nie tyle poszukiwania podatników, którzy nie dokonywali wcześniej tego odpisu, co przede wszystkim docierania do osób dokonujących wcześniej odpisów na rzecz innych organizacji. Wynika to również z faktu, że dominujące motywacje, jakie towarzyszą Polakom przy przekazywaniu „1"\%, to spontaniczność, a nierzadko przypadkowość w dokonywaniu wyborów organizacji oraz brak poczucia odpowiedzialności za to, komu przekazywane są środki i niepamięć o tym, kto jest ich dysponentem [Piechota, 2011, s. 111]. Tym samym OPP otrzymujące dotychczas znaczące fundusze w ramach "1\%", a zwłaszcza te opierające swoją działalność na tych środkach, muszą liczyć się z możliwością odpływu podatników decydujących się na odpisy podatkowe na rzecz innych organizacji. Niezwykle ważną kwestią jest zatem 
informowanie o wykorzystaniu otrzymanych funduszy, a przede wszystkim efektywności przedsiębranych działań. Pożądana jest transparentność w zakresie ponoszonych wydatków oraz wzmocnienie komunikacji z otoczeniem. Liderzy podmiotów ekonomii społecznej powinni zintensyfikować działania w zakresie utrzymania relacji z podatnikami, którzy dokonywali już wcześniej odpisu podatkowego „1\%”. Przy czym wiadomości trafiające do podatników nie powinny ograniczać się do jednorazowego ogólnego komunikatu. Pożądany jest ciąg działań charakterystyczny dla filozofii Customer Relationship Management (CRM) zakładającej, że pozyskanie nowego klienta jest znacznie droższe niż utrzymanie klienta wcześniej już zdobytego. Podatnik w stworzonym systemie „1\%" jest klientem „misji” OPP. Powyższe rekomendacje należy traktować jako poważne wyzwanie m.in. wobec faktu, iż zdecydowana większość podatników nie analizuje sprawozdań OPP, a wspiera organizacje, które pomagają bliskiej bądź znanej im osobie [Waniak-Michalak, Zarzycka, 2015, s. 131]. Kontekst ekonomii społecznej w tym wymiarze zanika.

Złożoność problematyki łączącej ekonomię społeczną, OPP i odpis „1\%", postępująca hybrydyzacja sektora pozarządowego nadmiernie uzależniającego się od pozostałych sektorów gospodarki oraz wyniki zrealizowanych badań wskazują rozległe pola badawcza wymagające rozpoznania naukowego. Pożądany wymiar poznawczy sprowadza się m.in. do problematyki gospodarowania OPP w warunkach ograniczonych zasobów oraz określenia determinant alokacji środków finansowych pozyskanych w ramach "1\%". Kolejne studia literaturowe oraz empiryczne

\section{Literatura}

Adamiak P. (2014). Zaangażowanie społeczne Polek i Polaków. Wolontariat, filantropia, 1\% i wizerunek organizacji pozarzadowych. Raport z badania 2013. Warszawa: Stowarzyszenie Klon/Jawor. badania jakościowe powinny zostać zorientowane m.in. na pełną analizę funkcjonalną instrumentu "1\%", uregulowania prawne, międzynarodowe studia porównawcze, jak również pomiar wiedzy, percepcji oraz skłonności krajowych podatników do wspierania OPP. Przekazane OPP środki w ramach „1\%” w 2016 r. sięgnęły 617,5 mln zł, co w znaczący sposób wpłynęło na funkcjonowanie wielu organizacji. Jednak niektóre z nich niemal w pełni uzależniły swoją działalność od przekazanych środków, świadomie rezygnując z dywersyfikacji źródeł przychodów, w tym m.in. wykorzystując system subkont. W tym kontekście niezwykle ważna w wymiarze poznawczym jest identyfikacja struktury rodzajowej przychodów oraz wydatków OPP. Ważne jest również uchwycenie relacji pomiędzy nakładami ponoszonymi na działania marketingowe związane z promocją "1\%" i przychodami z tego tytułu. Mechanizm „1\%” zyskując systematycznie na popularności znalazł się obecnie również w kręgu zainteresowania kolejnych potencjalnych grup beneficjentów tego instrumentu, wśród których pojawiły się m.in. partie polityczne, kościoły, a nawet media publiczne [Wygnański, 2016, s. 96]. Kolejne grupy zainteresowanych partycypacją w przychodach z "1\%" dysponują dużymi zasobami osobowymi, tym samym mogą przyczynić się do znacznego zwiększenia obecności tego instrumentu w praktyce OPP. Jednocześnie mogą również doprowadzić do zmniejszenia przychodów innych organizacji. W tym kontekście należy wskazać na kolejne wyzwanie badawcze związane z uchwyceniem relacji alokacji środków pozyskanych w ramach „1\%" w wymiarze określonych korzyści społecznych.

Adamiak P., Charycka B., Gumkowska M. (2016). Kondycja sektora organizacji pozarządowych w Polsce 2015. Raport z badań. Warszawa: Stowarzyszenie Klon/ Jawor. 
Bulczak G. (2014). „Zastosowanie Google Trends w prognozowaniu zmian na rynku nieruchomości", Zarzadzanie i Finanse, t. 12, nr 4

Choi H., Varian H. (2012). "Predicting the Present with Google Trends", Economic Record, Vol. 88.

Cooper C., Mallon K., Leadbetter S., Pollack L., Peipins L. (2005). "Cancer Internet Search Activity on a Major Search Engine, United States 2001-2003", Journal of Medical Internet Research, 7(3): e36.

CRSG (2013). Porównanie koncepcji wsparcia rozwoju ekonomii społecznej na poziomie regionalnym i krajowym na podstawie wieloletnich regionalnych planów działań na rzecz promocji i upowszechnienia ekonomii społecznej oraz rozwoju instytucji sektora ekonomii społecznej i jej otoczenia w regionie oraz projektu Krajowego Programu Rozwoju Ekonomii Społecznej. Szczecin: Centrum Rozwoju Społeczno-Gospodarczego.

Czetwertyński S. (2016). „Konkurencja na rynku jednego procenta", Społeczeństwo i Ekonomia, nr 1 (5).

Ettredge M., Gerdes J., Karuga G. (2005). „Using Web-based Search Data to Predict Macroeconomic Statistics", Communications of the ACM, Vol. 48, No. 11.

Goel S., Hofman J.M., Lahaie S., Pennock D.M., Watts D.J. (2010). "Predicting consumer behavior with Web search", Proc Natl Acad Sci USA, 12; 107(41).

Google Trends, https://trends.google.pl (dostęp: 31.05.2017).

Grzybowska A., Ruszewski J. (2010). Ekonomia społeczna w teorii i praktyce. Suwałki: Centrum Aktywności Społecznej PRYZMAT.

GUS (2017a). Organizacje pożytku publicznego i 1\% (notatka informacyjna). Warszawa: Główny Urząd Statystyczny.

GUS (2017b). Projekty unijne: Zintegrowany System Monitorowania Sektora Ekonomii Społecznej (ZSMSES), http://stat.gov.pl/projekty-unijne-w-statystyce/zsmses/ (dostęp: 15.05.2017)

Herbst I. (2012). „Finansowanie podmiotów ekonomii społecznej w Polsce". Ekonomia Społeczna, nr 1.

Jegorow D. (2016). „Organizacje pozarządowe jako beneficjent polityki spójności Unii Europejskiej doświadczenia Polski", Ekonomika i Organizacja Przedsiębiorstw, nr 3 (794).

Jegorow D. (2017a). „Ekonomizacja sektora pozarządowego w Polsce", Zeszyty Naukowe Politechniki Ślaskiej. Organizacja i Zarządzanie, z. 105.

Jegorow D. (2017b). „Organizacje pozarządowe jako podmioty zależne od funduszy pomocowych na przykładzie Programu Operacyjnego Kapitał Ludzki", Zeszyty Naukowe Politechniki Śląskiej. Organizacja i Zarządzanie, z. 105.

Kietlińska K. (2015). „Rola 1\% w zasilaniu organizacji pożytku publicznego (OPP)", Prace Naukowe Uniwersytetu Ekonomicznego we Wrocławiu, nr 403.
KPRES (2014). Uchwała nr 164 Rady Ministrów z dnia 12 sierpnia 2014 r. w sprawie przyjęcia programu pod nazwą "Krajowy Program Rozwoju Ekonomii Społecznej". M.P. 2014 poz. 811.

Królikowska A. (2005). „Finansowanie instytucji ekonomii społecznej", Trzeci Sektor, nr 2.

Makowski G. (2011). "Czy mechanizm jednego procentu jest publicznie pożyteczny?", Trzeci Sektor, nr 24.

MF (2010). Informacja na temat kwot 1\% należnego podatku dochodowego od osób fizycznych przekazanych organizacjom pożytku publicznego z zeznań za 2009 rok. Warszawa: Ministerstwo Finansów.

MF (2016). Informacje dotyczace kwot 1\% należnego podatku dochodowego od osób fizycznych przekazanych organizacjom pożytku publicznego z rozliczenia za 2015 rok. Warszawa: Ministerstwo Finansów.

MF (2017). PIT: Statystyki. Ministerstwo Finansów, http://www.finanse.mf.gov.pl/pit/statystyki/-/document_library_display/8Wpj/view/1182889 (dostęp: 20.05.2017).

MR (2017). Wsparcie dla Podmiotów Ekonomii Społecznej z POWERa. Ministerstwo Rozwoju, http:// www.power.gov.pl/Strony/wiadomosci/Wsparciedla-Podmiotow-Ekonomii-Spolecznej-z-POWERa (dostęp: 25.05.2017).

Perkowski T. (2011). „Mechanizm jednego procentu jako 'fałszywa' filantropia". Trzeci Sektor, nr 24.

Piechota G. (2011). Organizacje pożytku publicznego w drodze do społeczeństwa obywatelskiego? Katowice: Śląska Biblioteka Cyfrowa.

Piechota G. (2015). Fakty i mity o jednym procencie podatku. Odpis podatkowy w procesie kreowania społeczeństwa obywatelskiego. Kraków: Universitas.

Solecki S. (2013). „Ekonomia społeczna i jej wrogowie", Nierówności społeczne a wzrost gospodarczy, nr 33.

Vosen S., Schmidt T. (2011). „Forecasting private consumption: survey-based indicators vs. Google trends", Journal of Forecasting, 30(6).

Waniak-Michalak H., Zarzycka E. (2015), „Wykorzystanie informacji przez darczyńców w Polsce - przykład darowizn 1\% podatku dochodowego", Zeszyty Teoretyczne Rachunkowości, Vol. 139 (83).

Wygnański K. (2016). "Country report: Poland”, w: B. Strečanský, M. Török (red.), Assessment of the Impact of the Percentage Tax Designations: Past, Present, Future. Vienna: ERSTE Foundation.

Yunus M. (2011). Przedsiębiorstwo społeczne. Kapitalizm dla ludzi. Warszawa: ConCorda.

Yunus M. (2013). Świat bez ubóstwa. Czas na przedsiębiorstwo społeczne. Warszawa: ConCorda. 
Tax deduction " $1 \%$ " as a source of financing for the social economy in Poland: Retrospection and projection of the level of social involvement

Summary: One of the basic problems of social economy entities is maintaining independence and financial stability. Meanwhile, dependence on public support has dominated the main sources of funding for public benefit organizations. In this context, the revenue generated by the " $1 \%$ " tax deduction should also be considered. Over ten years of this solution existence, $49 \%$ of the total number of taxpayers was covered. A marked slowdown in this trend indicates that the potential maximum absorption is approaching. This situation should lead to the rethinking of the new marketing strategy by the organizations earning high revenues under the " $1 \%$ " tax deduction, and also these, who are planning to use this form of support to potential benefit.

Keywords: social economy, tax deduction "1\%", public benefit organization, non-governmental sector.

\section{Prawa autorskie i licencja / Copyright and License}

Artykuł opublikowano na licencji Creative Commons

Uznanie autorstwa - Użycie niekomercyjne - Bez utworów zależnych 3.0 Polska http://creativecommons.org/licenses/by-nc-nd/3.0/pl/

This article is published under the terms of the Creative Commons Attribution - NonCommercial - NoDerivs (CC BY-NGND 3.0) License http://creativecommons.org/licenses/by-nc-nd/3.0/ 